\title{
EFEKTIFITAS PROGRESSIVE MUSCLE RELAXATION (PMR) TERHADAP PENURUNAN TEKANAN DARAH PADA PENDERITA HIPERTENSI
}

\section{(EFFECTIVENESS OF PROGRESSIVE MUSCLE RELAXATION (PMR) ON BLOOD PRESSURE REDUCTION IN HYPERTENSION PATIENTS)}

\author{
Primasari Mahardhika Rahmawati ${ }^{1}$, Musviro $^{2}$, Fitrio Deviantony ${ }^{3}$ \\ ${ }^{1,2}$ Staf Pengajar Program Studi D3 Keperawatan Universitas Jember Kampus Lumajang, \\ ${ }^{3}$ Staf Pengajar Fakultas Keperawatan Universitas Jember
}

\begin{abstract}
ABSTRAK
Hipertensi merupakan faktor risiko utama untuk penyakit kardiovaskular dan membawa beban kesehatan yang tinggi dalam hal morbiditas dan mortalitas. Hipertensi merupakan faktor yang berkonstribusi terhadap kematian akibat stroke dan faktor yang memperberat infark miokard. Salah satu upaya untuk menurunkan tekanan darah pada penderita hipertensi diantaranya adalah dengan terapi relaksasi otot progresif (Progressive Muscle Relaxation/ PMR). Mengetahui efektifitas terapi PMR terhadap penurunan tekanan darah pada penderita hipertensi kelompok "Prolanis" di wilayah kerja Puskesmas Jatiroto Kabupaten Lumajang. Desain Penelitian menggunakan desain pre eksperiment dengan rancangan one group pre test post test. Teknik sampling menggunakan teknik consecutive sampling dengan jumlah sampel sebanyak 24 responden. Pelaksanaan terapi PMR menggunakan tool atau standard operating procedures (SOP) terapi PMR. Instrument untuk mengukur tekanan darah dengan menggunakan Sphygmomanometer digital merk Omron. Terdapat perbedaan yang signifikan pada tekanan darah baik systole dan diastole responden sebelum dan sesudah diberikan terapi PMR. Hal ini dibuktikan dengan nilai $\mathrm{p}$ melalui uji T didapatkan nilai $\mathrm{p}$ 0,000 dimana nilai $\mathrm{p}<0,05$ dan nilai $95 \%$ Confidence Interval tidak melewati angka nol. Terapi relaksasi otot progresif signifikan menurunkan tekanan darah pada penderita hipertensi sehingga terapi ini dapat dijadikan salah satu alternatif terapi sebagai terapi non farmakologis dalam menurunkan tekanan darah bagi penderita hipertensi.
\end{abstract}

Kata Kunci: relaksasi otot progresif, tekanan darah, hipertensi.

\section{ABSTRACT}

Hypertension is a major risk factor for cardiovascular disease and carries a high burden of health in terms of morbidity and mortality. Hypertension is a contributing factor to death from stroke and factors that exacerbate myocardial infarction. One effort to descrease blood pressure such as progressive muscle relaxation therapy (Progressive Muscle Relaxation/PMR). To know the effectiveness of PMR therapy on the decrease of blood pressure in hypertension group of "Prolanis" in Jatiroto Health Center Lumajang. The research design used pre experiment design with one group pre test post test. Sampling technique using consecutive sampling technique with the number of samples of 26 respondents. Implementation of PMR therapy using PMR therapy tool or standard operating procedures (SOP). Instrument for measuring blood pressure using Omron brand digital sphygmomanometer. There were significant differences in blood pressure in both systole and diastolic respondents before and after PMR therapy. This is evidenced by the value of $p=$ 0,000 where the $p$ value $<0.05$ and the value of $95 \%$ Confidence Interval does not pass zero. Progressive muscle relaxation therapy significantly descreased blood pressure so this therapy can be used as an alternative therapy as non-pharmacological therapy in lowering blood pressure for hypertensive patients.

Keywords: Progressive Muscle Relaxation (PMR), blood pressure, hypertension.

\section{PENDAHULUAN}

Hipertensi adalah salah satu faktor pemicu penyakit jantung dan stroke yang menjadi penyebab kematian teratas didunia. Hipertensi disebut silent killer, setiap tahun 9,4 juta warga dunia meninggal karena hipertensi (Kemenkes RI, 2014). Data Global Status Report on Noncommunicable Disesases (2010) dari WHO menyebutkan bahwa $40 \%$ negara berkembang menderita hipertensi. Negara berkembang memiliki prosentase lebih banyak menderita hipertensi. Di Asia Tenggara 36\% orang dewasa menderita hipertensi dan telah membunuh 1,5 juta orang setiap tahunnya. Di Indonesia, hipertensi sampai saat ini menjadi tantangan masalah kesehatan dengan prevalensi tinggi. Pada tahun 2013, secara nasional $25,8 \%$ penduduk Indonesia mengalami hipertensi (Kemenkes RI, 2014). 
Hipertensi merupakan peningkatan tekanan darah sistolik lebih dari $140 \mathrm{mmHg}$ dan tekanan darah diastolik lebih dari 90 mmHg pada dua kali pengukuran dengan selang waktu lima menit dalam keadaan cukup istirahat/tenang. Peningkatan tekanan darah dalam jangka waktu lama (persisten) dapat menimbulkan kerusakan pada ginjal (gagal ginjal), jantung (penyakit jantung koroner) dan otak (menyebabkan stroke), sehingga tatalaksana hipertensi diperlukan dengan baik. The Sevent Report Of The Joint National Committee on Prevention, Detection, Evaluation, and Treatment of High Blood Pressure (JNC 7) merekomendasikan modifikasi gaya hidup tunggal saat tekanan darah $>120 / 80 \mathrm{mmHg}$ dan $<140 / 90 \mathrm{mmHg}$ (pre hipertensi), pada tekanan darah $\geq 140 / 90 \mathrm{mmHg}$ yaitu tahap 1 dengan modifikasi gaya hidup antara lain berat badan, aktivitas fisik, asupan natrium, buah-buahan, sayuran, lemak jenuh dan total serta alkohol. Modifikasi gaya hidup dengan pengurangan stress untuk pasien normotensif dan hipertensi direkomendasi Canadian Hypertension Education Program dalam tatalaksana hipertensi. Stress psikososial terbukti berkontribusi terhadap tekanan darah tinggi. Komplikasi tekanan darah tinggi dapat menyebabkan pasien mengalami kecemasan dan stress (Smeltzer, et al., 2008).

Stress merupakan faktor resiko independen utama pada hipertensi. Stress mengendalikan sistem saraf simpatis dan korteks adrenal melalui aktivasi hipotalamus. Sistem saraf simpatis juga memberikan sinyal ke medulla adrenal untuk melepaskan epineprin dan norepineprin ke aliran darah (Sherwood, 2010). Stimulasi aktivitas saraf simpatis akan meningkatkan resistensi pembuluh darah perifer dan curah jantung sehingga mempengaruhi peningkatan tekanan darah. Pada stress akut, dipicu oleh sistem saraf simpatik dan hipotalamuspituitari-axis adenocortical sehingga terjadi peningkatan curah jantung, heart rate dan resistensi perifer dan pada stress kronik terjadi hiperaktivasi persisten sistem saraf simpatis dan hipotalamus-pituitari-axis adrenocortical.

Teknik relaksasi dapat menghambat respon stress saraf simpatis, otot-otot pembuluh darah arteri dan vena bersamaan dengan otot-otot lain dalam tubuh menjadi rileks. Relaksasi otot-otot dalam tubuh berpengaruh terhadap penurunan kadar norepineprin dalam tubuh (Shinde, et all, 2013). Salah satu teknik relaksasi sebagai upaya menurunkan tekanan darah adalah dengan terapi relaksasi otot progresif atau Progressive Muscle Relaxation (PMR).
Progressive Muscle Relaxation (PMR) merupakan salah satu bentuk terapi relaksasi dengan gerakan mengencangkan dan merelaksasikan otot-otot satu bagian tubuh pada satu waktu untuk mendapatkan kontrol atas kecemasan yang merangsang pikiran dan ketegangan otot (Keliat \& Pasaribu, 2016).

Hasil riset terdahulu tentang Progressive Muscle Relaxation (PMR) antara lain Fraser, Matsuzakawal, Lee1, dan Minen (2017) yang menyatakan bahwa PMR adalah salah satu nonpharmacologic treatment bagi penderita PTH (PostTraumatic Headache) dan penelitian Meyer, et al. (2016), menyatakan bahwa setelah terapi PMR, pasien migrain menunjukkan pengurangan frekuensi migrain. Riset yang dilakukan Kasron (2017) juga menunjukkan bahwa terdapat pengaruh pemberian PMR dengan kualitas tidur penderita hipertensi di Cilacap Selatan. Menurut Rainfort, et all (2007), substansial evidence menunjukkan bahwa stress psikososial berkontribusi pada hipertensi dan penyakit kardiovaskuler (CVD). Dari hasil sistematic review dari literatur dan identifikasi 107 penelitian dalam mengurangi stress dan tekanan darah, PMR dapat mengurangi stress dan tekanan darah yaitu $-1,9 /-1,4 \mathrm{mmHg}$. Dari latar belakang tersebut, peneliti ingin menganalisis lebih lanjut pengaruh terapi Progressive Muscle Relaxation (PMR) terhadap penurunan tekanan darah. Tujuan penelitian ini yaitu mengetahui efektifitas terapi PMR terhadap penurunan tekanan darah pada penderita hipertensi kelompok "Prolanis" di wilayah kerja Puskesmas Jatiroto Kabupaten Lumajang.

\section{METODE}

Desain Penelitian menggunakan desain pre eksperiment dengan rancangan one group pre test post test. Teknik sampling menggunakan teknik consecutive sampling dengan jumlah sampel sebanyak 24 responden. Pelaksanaan terapi PMR menggunakan tool atau standard operating procedures (SOP) terapi PMR. Instrument untuk mengukur tekanan darah dengan menggunakan Sphygmomanometer digital merk Omron. Uji analisis statistik yang digunakan adalah uji parametric paired t-test untuk menganalisis perbedaan tekanan darah responden sebelum (pre) dan sesudah (post) diberikan terapi PMR.

\section{Hasil}

Tabel 1. Karakteristik Responden Berdasarkan Usia, Jenis Kelamin, Pendidikan dan Pekerjaan 


\begin{tabular}{|c|c|c|c|}
\hline $\begin{array}{c}\text { Varia } \\
\text { bel }\end{array}$ & Kategori & $\mathbf{n}$ & $\%$ \\
\hline Usia & $\begin{array}{l}41-50 \\
\text { tahun } \\
>51 \\
\text { tahun }\end{array}$ & $\begin{array}{r}5 \\
19\end{array}$ & $\begin{array}{l}20,83 \% \\
79,17 \%\end{array}$ \\
\hline Jenis & Pria & 3 & \\
\hline Kelamin & Wanita & 21 & $\begin{array}{l}12,50 \% \\
87,50 \% \\
\end{array}$ \\
\hline $\begin{array}{c}\text { Pendidik } \\
\text { an }\end{array}$ & 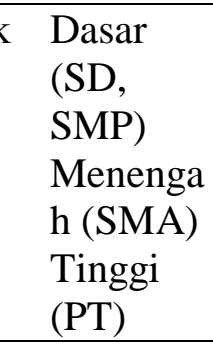 & 15 & $\begin{array}{l}62,50 \% \\
25,00 \% \\
12,50 \%\end{array}$ \\
\hline $\begin{array}{c}\text { Pekerjaa } \\
n\end{array}$ & $\begin{array}{l}\text { Tidak } \\
\text { bekerja } \\
\text { Swasta } \\
\text { Wiraswa } \\
\text { sta } \\
\text { PNS/ } \\
\text { TNI }\end{array}$ & $\begin{array}{r}12 \\
3 \\
4 \\
5\end{array}$ & $\begin{array}{c}50,00 \% \\
12,50 \% \\
16,67 \% \\
20,83 \%\end{array}$ \\
\hline
\end{tabular}

Berdasarkan tabel 3.1 menunjukkan bahwa sebagian besar responden yang menderita hipertensi berusia diatas 51 tahun dengan persentase $79,17 \%, 87,5 \%$ responden berjenis kelamin wanita, $62,5 \%$ berpendidikan dasar dan $50 \%$ responden tidak bekerja.

Tabel 2. Perbedaan Tekanan Darah Klien Hipertensi Sebelum dan Sesudah Diberikan Terapi PMR

\begin{tabular}{lccccc}
\hline & Mean & Selisih & $\begin{array}{c}\mathbf{9 5 \%} \\
\mathbf{C I}\end{array}$ & $\mathbf{T}$ & $\begin{array}{c}\mathbf{p} \\
\text { value }\end{array}$ \\
$\begin{array}{l}\text { TDS pre } \\
(\mathrm{n}=24)\end{array}$ & 133,85 & 10,00 & 7,53 & 8,83 & 0.000 \\
TDS \\
$\begin{array}{l}\text { post } \\
(\mathrm{n}=24)\end{array}$ & 123,85 & & - & & \\
& & & 12,47 & & \\
$\begin{array}{l}\text { TDD pre } \\
(n=24)\end{array}$ & 93.08 & 9,23 & 6,25 & 6,74 & 0,000 \\
$\begin{array}{l}\text { TDD } \\
\text { post } \\
(n=24)\end{array}$ & 83.85 & & 12,21 & & \\
\hline
\end{tabular}

Tabel 3.2 menunjukkan bahwa terdapat perbedaan yang signifikan pada tekanan darah (systole dan diastole) sebelum dan sesudah diberikan terapi relaksasi otot progresif dibuktikan dengan nilai p 0,000 dimana nilai $\mathrm{p}<0,05$ dan nilai $95 \%$ Confidence Interval tidak melewati angka nol. Secara klinis pun juga dapat dikatakan terdapat perbedaan tekanan darah sebelum dan sesudah diberikan terapi PMR dengan selisih nilai 10 pada tekanan darah systole dan selisih nilai 9,23 pada tekanan darah diastole.

\section{PEMBAHASAN}

Hasil penelitian menunjukkan bahwa $87,5 \%$ responden berjenis kelamin wanita. Hal ini sesuai dengan pernyataan Triyanto (2014) dalam Rusnoto dan Alviana (2017) yang mencatat sedikitnya sejumlah 839 juta kasus hipertensi pada Tahun 2012 dan diperkirakan mengalami peningkatan kasus menjadi 1,15 milyar pada tahun 2025 atau sekitar $29 \%$ dari total penduduk dunia, dimana penderitanya lebih banyak dialami wanita dibandingkan pria. 79,17\% responden dalam penelitian ini berusia diatas 51 tahun dan sesuai dengan teori yang dikemukakan Cohen (2009) bahwa penyakit hipertensi cenderung dialami pada usia kelompok 4554 tahun dimana usia ini merupakan usia yang produktif. Hasil penelitian juga menunjukkan adanya perbedaan yang signifikan pada tekanan darah baik systole maupun diastole sebelum dan sesudah diberikan terapi PMR dengan adanya selisih nilai pada tekanan darah systole maupun diastolenya. Hal ini sesuai dengan teori Setyoadi dan Kushariyadi (2011) yang menyatakan bahwa salah satu tujuan diberikannya terapi PMR ini adalah untuk menurunkan ketegangan otot, kecemasan, nyeri leher dan punggung, tekanan darah tinggi, frekuensi jantung, dan laju metabolik.

Terapi PMR akan menghasilkan adanya relaksasi pada tubuh sehingga dapat menghambat peningkatan saraf simpatetik yang diharapkan agar hormon penyebab disregulasi tubuh dapat dikurangi jumlahnya. Sistem saraf parasimpatetik adalah sistem yang mendominasi pada keadaan tenang dan santai memiliki fungsi kerja berlawanan dengan saraf simpatetik akan memperlambat atau memperlemah kerja alat-alat internal tubuh sehingga akan terjadi penurunan detak jantung, irama nafas, tekanan darah, ketegangan otot, dan tingkat metabolisme (Praptini, 2014). Hal ini didukung dengan hasil penelitian yang menunjukkan adanya perbedaan tekanan darah dan nadi setelah diberikan intervensi terapi PMR dimana terjadi penurunan tekanan darah baik sistolik maupun diastolik serta penurunan nadi seiring dengan turunnya skor kecemasan responden. Penelitian yang dilakukan Santidar (2016) juga membuktikan bahwa terapi PMR lebih efektif menurunkan tekanan darah daripada terapi tertawa. Penelitian terbaru yang dilakukan oleh Setyaningrum dan Badi'ah (2018) membuktikan bahwa terapi progressive muscle relaxation yang dikombinasikan dengan zikir secara bersamaan efektif 
menurunkan tekanan darah dan stress pada penderita hipertensi.

Synder dan Lindquist (2002) menyatakan bahwa selama maupun setelah melakukan terapi PMR akan terjadi perubahan dalam tubuh seperti merasa tenang, ringan dan klien akan merasakan sensasi kehangatan yang menyebar ke seluruh tubuh. Respon emosi dan efek sensasi menenangkan yang ditimbulkan oleh terapi relaksasi ini akan mengubah fisiologi dominan sistem saraf simpatis menjadi dominan sistem saraf parasimpatis sehingga akan menurunkan regulasi sumbu HPA yang overaktif (McCloughan, Hanrahan, Anderson, \& Halson, 2016). Diperkuat dengan pernyataan bahwa PMR dapat meningkatkan hormon parasimpatis dan neurotransmiter seperti DHEA (Dehidroepinandrosteron), dopamine atau endorfin dan enkefalin serta merangsang signal otak sehingga otot rileks. yang disertai dengan penurunan tekanan darah (Conrad \& Roth, 2007; Lestari \& Yuswiyanti, 2015). Saat otot rileks, maka tubuh akan membentuk hormone beta-endorfin yang akan membantu mengembalikan kondisi pembuluh darah menjadi normal seperti semula dan menjaga agar darah dapat mengalir dengan mudah dan bebas hambatan sehingga terjadi penurunan tekanan darah (Haruyama, 2011).

Implementasi terapi PMR dalam penelitian ini dibagi menjadi tiga sesi yang dilaksanakan secara langsung dengan alokasi waktu sekitar 30-45 menit. Sesi pertama terapi PMR ini adalah mengidentifikasi ketegangan otot tubuh tertentu yang dirasakan disertai dengan penjelasan singkat tentang prosedur, tujuan serta manfaat dari dilakukannya teknik terapi PMR. Responden diharapkan dapat memahami prosedur, tujuan dan manfaat dari terapi yang akan dilakukan sehingga responden dapat menerapkan terapi yang telah diajarkan sebagai salah satu tindakan untuk menurunkan tekanan darah. Sesi kedua adalah aplikasi terapi PMR, peneliti memutarkan musik klasik untuk mengiringi pelaksanaan terapi dan responden diminta untuk menarik nafas dalam dan menghembuskan secara perlahan sebanyak tiga kali. Responden kemudian diinstruksikan untuk menegangkan setiap kelompok otot selama kurang lebih 10 detik dimulai dari otot dahi dan mata, otot mulut, otot rahang, otot leher, otot punggung, otot dada, otot tangan, otot bisep dan otot paha diiringi oleh penjelasan terapis terkait dengan ketidaknyamanan yang dirasakan klien saat kondisi otot tegang. Setelah itu terapis menginstruksikan responden untuk mengendorkan setiap kelompok otot yang ditegangkan tadi diiringi dengan penjelasan terapis terkait perbandingan perasaan ketika otot tersebut tegang dan ketika otot dilemaskan sehingga perasaan pada otot saat dilemaskan menjadi relaks (Rahmawati, Widjajanto, \& Astari, 2017).

Sesi terakhir dalam pelaksanaan terapi PMR ini adalah mengevaluasi kemampuan responden dalam melakukan terapi PMR yang telah diajarkan oleh peneliti (Keliat \& Pasaribu, 2016). Evaluasi dalam sesi ketiga dilakukan untuk menilai sejauh mana responden mampu melakukan semua gerakan terapi mulai awal hingga akhir terapi. Bila responden belum mampu melakukan semua gerakan dalam terapi yang telah diajarkan maka peneliti mengulangi kembali pelaksanaan terapi PMR mulai sesi pertama.

Synder dan Lynquist (2002) menegaskan bahwa dengan melakukan terapi PMR maka akan dapat memberikan dampak langsung pada respon fisik sehingga kemampuan relaksasi pasien dapat meningkat. Prosedur terapi PMR bertujuan untuk mendapatkan kondisi relaks pada otot melalui dua langkah, yakni dengan memberikan tegangan pada suatu kelompok otot, dan dengan menghentikan tegangan tersebut kemudian memusatkan perhatian terhadap bagaimana otot tersebut menjadi relaks, merasakan sensasi relaks secara fisik sehingga ketegangan yang dirasakan menghilang (Richmond, 2007). Keadaan otot yang rileks akan menyebarkan stimulus ke hipotalamus sehingga akan menekan sistem saraf simpatis sehingga terjadi penurunan produksi hormon epinefrin dan norepinefrin. Penurunan hormone tersebut akan menyebabkan penurunan kecepatan denyut jantung, volume sekuncup juga akan menurun, serta terjadi vasodilatasi arteriol dan venula. Selain itu curah jantung, resistensi perifer total juga menurun sehingga tekanan darah juga akan turun. Modifikasi gaya hidup dan teknik relaksasi dapat menormalkan tekanan darah pada klien dengan hipertensi (Black \& Hawk, 2005)

\section{KESIMPULAN}

Kesimpulan dalam penelitian ini adalah terdapat perbedaan yang signifikan tekanan darah responden post diberikan terapi Progressive Muscle Relaxation (PMR) baik tekanan darah systole maupun diastole. Terapi PMR signifikan menurunkan tekanan darah pada penderita hipertensi khususnya pada kelompok Prolanis di wilayah kerja Puskesmas Jatiroto. Terapi Progressive Muscle Relaxation (PMR) dapat dijadikan sebagai 
salah satu kompetensi untuk menurunkan tekanan darah pada penderita hipertensi yang harus dilakukan perawat baik yang berada di tatanan pelayanan kesehatan rumah sakit maupun di tatanan masyarakat.

\section{SARAN}

Berdasarkan kajian dalam penelitian ini maka disarankan kepada penderita hipertensi untuk melakukan terapi PMR secara kontinyu sebagai salah satu bentuk aktivitas fisik disamping modifikasi gaya hidup ke arah pola hidup sehat serta secara berkala melakukan pemeriksaan tekanan darahnya.

\section{KEPUSTAKAAN}

Antari, N. K. A. J., Artini, I., \& Andayani, N. 2016. Aplikasi Progressive Muscle Relaxation Terhadap Penurunan Tekanan Darah Pada Hipertensi Derajat I Di Kota Denpasar. Program Studi Fisioterapi Fakultas Kedokteran Universitas Udayana, Denpasar Bali.

Black, J., \& Hawk, J. 2005. Medical Surgical Nursing Clinical Mnagement for Positive Outcome (7th Ed ed.). Philadelphia: Mosbi.

Cohen, J. D. 2009. Hypertension Epidemiology and Economic Burden : Refining Risk Assessment To Lower Costs. Managed Care, (October), 51-58.

Conrad, A. \& Roth, W. T. 2007. Muscle relaxation therapy for anxiety disorders: it work but how? Journal of Anxiety Disorders, 21 (3), 243-264

Fraser F, Matsuzakawal, Lee1, Y.S.C, \& Minen M. 2017. Behavioral Treatments For Post-Traumatic Headache. Curr Pain Headache Rep. (2017) 21: 22 Doi 10.1007/S11916-017-0624-X.

Haruyama, S. 2011. The Miracle of Endorphin. Bandung: Mizan Media Utama.

Kasron, Susilawati. 2017. Pengaruh Progressive Muscle Relaxation Terhadap Kualitas Tidur Penderita Hipertensi Di Cilacap Selatan. Jurnal Keperawatan dan Pemikiran Ilmiah. 3 (3). 20-28.

Keliat, B. A. \& Pasaribu, J. 2016. Prinsip dan Praktik Keperawatan Kesehatan Jiwa Stuart. Singapore: Elsevier

Kemenkes, RI. 2014. INFODATIN. Pusat Data dan Informasi Kementerian
Kesehatan RI. HIPERTENSI. Jakarta.

Lestari \& Yuswiyanti. (2014). Pengaruh Relaksasi Otot Progresif Terhadap Penurunan Tingkat Kecemasan pada Pasien Pre Operasi di Ruang Wijaya Kusuma RSUD Dr R Soeprapto Cepu, J. Keperawatan Matern. vol 2, no 1, pp. 7-11.

McCloughan, L. J., Hanrahan, S., J., Anderson, R., \& Halson, S. R. 2016. Psychological recovery: Progressive muscle relaxation (PMR), anxiety, and sleep in dancers. Performance Enhancement \& Health, 4: 1217.

Meyer, B., Keller A., Wöhlbier H-G., Claudia H.O., Muller B., and Kropp P. 2016. Progressive Muscle Relaxation Reduces Migraine Frequency And Normalizes Amplitudes Of Contingent Negative Variation (Cnv). The Journal Of Headache And Pain. 2016. 17:37 Doi 10.1186/S10194-016-0630-0.

Praptini, D. 2014. Pengaruh Relaksasi Otot Progresif Terhadap Tingkat Kecemasan Pasien Kemoterapi di Rumah Singgah Kanker Denpasar. COPING NERS (Community of Publishing in Nursing), 2(3).

Rahmawati, P. M., Widjajanto, E., \& Astari, A. M. 2017. The Influence of Progressive Muscle Relaxation on Anxiety Level of Pre-caesarean Section Mothers in Delivery Room. NurseLine Journal, 2(2), 117-125.

Rainforth M. V., Schneider R. H., Nidich S. I., Gaylord-King C., Salerno J. W. and Anderson J. W. 2007. Stress Reduction Programs In Patients With Elevated Blood Pressure: A Systematic Review And Meta-Analysis. Current Hypertension Reports 2007, 9:520-528.

Richmond, R.L. 2007. A Guide to Psychology and its Practice. Diunduh dari http://www.guidetopsychology.co m/pmr.html

Rusnoto \& Alviana, I. 2017. Pengaruh terapi progressive muscle relaxation terhadap penurunan tekanan darah pada peserta prolanis. THE 5TH URECOL PROCEEDING UAD Yogyakarta. 
Santidar, D.V.P. 2016. Relaksasi otot progresif dan terapi tertawa untuk menurunkan tekanan darah hipertensi di Dusun Mejing Lor Ambarketawang Gamping Sleman Yogyakarta. Naskah publikasi. PSIK FIK Universitas "Aisyiyah Yogyakarta.

Setyaningrum, N. dan Badi'ah, A. 2018. Efektivitas Progressive Muscle Relaxation Dengan Zikir Terhadap Penurunan Tekanan Darah Dan Penurunan Tingkat Stres Pada Penderita Hipertensi. Medisains: Jurnal Ilmiah Ilmu-Ilmu Kesehatan, Vol 16 No 1, April 2018.

Setyoadi \& Kushariyadi. 2011. Terapi Modalitas Keperawatan Jiwa pada Klien Psikogeriatrik. Salemba Medika: Jakarta.

Sherwood, L. 2010. Human Physiology : From Cells To Systems. Usa: Yolanda Cossio.

Shinde, et al., 2013; Immediate effect of Jacobson's progressive muscle relaxation in hypertension; Indian Journal of Physiotherapy and Occupational Therapy, Vol.7, no.3.

Smeltzer, S.C., Bare, B.G., Hinkle, J.L., \& Cheever, K, H. 2008. Textbook Of Medical-Surgical Nursing. Eleventh Edition. Brunner, \& Suddarth's. Philadhelpia Lippincott Williams \& Wilkins, A Wolter Kluwer Bussiness.

Synder, M. \&Lyndquist, R. 2002. Complementary/ alternative therapies in nursing $\left(4^{\text {th }}\right.$ ed $)$. New York: Springer Publishing ompany. 